\title{
Evaluation of anti-psychotic effect of nimodipine using methylphenidate as a model to induce psychosis in albino mice
}

\author{
Hemant Tanwani ${ }^{1}$, Sheetal P. Pandey ${ }^{2}$, Shubham Atal $^{1}$, Prem Nyati $^{3}$
}

\begin{abstract}
${ }^{1}$ Department of Pharmacology, M.G.M. Medical College, Indore, MP, India, ${ }^{2}$ Madhya Pradesh Medical Science University, Jabalpur, MP, India, ${ }^{3}$ Department of Pharmacology Index Medical College and Research Center, Indore, Jabalpur, MP, India
\end{abstract}

Received: 02 October 2015 Accepted: 24 October 2015

*Correspondence to:

Dr. Shubham Atal,

Email: shubham.atal@gmail.com

Copyright: (c) the author(s), Academy. This is an open-access article distributed under the terms of the Creative Commons Attribution Non-Commercial License, which permits unrestricted non-commercial use, distribution, and reproduction in any medium, provided the original work is properly cited. publisher and licensee Medip

\begin{abstract}
Background: Schizophrenia is a functional psychotic disorder currently treated by typical and atypical antipsychotic drugs. A large group of patients remain resistant to therapy. Nimodipine has been found effective for treating resistant bipolar mood disorder which is linked genetically with schizophrenia and has a high overlap of neurotransmitters in the etiopathology. Previous studies to evaluate nimodipine's antipsychotic activity have shown inconsistent results. Methylphenidate, a CNS stimulant like amphetamine, has been shown to induce stereotypy in animals and can be proposed as an alternative model for psychosis.
\end{abstract}

Methods: Methylphenidate $5 \mathrm{mg} / \mathrm{kg}$ was given intraperitoneally to induce psychosis in swiss albino mice $(n=6)$. Nimodipine was given alone in doses of 2.5 and $5 \mathrm{mg} / \mathrm{kg}$ by i.p route and in combination with haloperidol $0.1 \mathrm{mg} / \mathrm{kg}$ and effects were compared with haloperidol $0.2 \mathrm{mg} / \mathrm{kg}$. Activity of nimodipine was also assessed on the haloperidol induced catalepsy test. Statistical analysis was done with ANOVA followed by Bonferroni's test using SPSS v. 20.0.

Results: Methylphenidate successfully induced characteristic stereotypy behaviour in mice similar to amphetamine. Both nimodipine $5 \mathrm{mg} / \mathrm{kg}$ and haloperidol $0.2 \mathrm{mg} / \mathrm{kg}$ showed significant reduction in stereotypy behaviour with no statistical difference between the two; result with nimodipine were only slightly inferior to haloperidol. Nimodipine $5 \mathrm{mg} / \mathrm{kg}$ with haloperidol $0.1 \mathrm{mg} / \mathrm{kg}$ showed significantly better activity than haloperidol in standard dose of 0.2 $\mathrm{mg} / \mathrm{kg}$. Nimodipine did not show significant activity on the haloperidol induced catalepsy test.

Conclusions: Methylphenidate has potential to be used as an alternative model for inducing psychosis in animals and nimodipine shows promising results for use as adjuvant antipsychotic drug.

Keywords: Nimodipine, Methylphenidate, Psychosis, Haloperidol, Stereotypy, Catalepsy

\section{INTRODUCTION}

Psychosis is a symptom of mental illnesses characterized by a loss of sense of reality. Common psychotic disorders include mood disorders (major depression or mania) with psychotic features, substance-induced psychosis, dementia or delirium with psychotic features, delusional disorder, schizoaffective disorder, and schizophrenia. Schizophrenia has a prevalence of $1 \%$ in the world and is considered the prototypic disorder for understanding the phenomenology of psychosis and the impact of antipsychotic treatment. ${ }^{1}$ Schizophrenia presents with symptoms like disorganized and bizarre thoughts (cognition), actions (conation) and behavior (affect). The symptomatology of schizophrenia includes (1) positive symptoms - auditory hallucinations, delusions, combativeness and suspiciousness. (2) Negative symptoms -anhedonia, avolition, ambitendency, affect flattening and slowness of activity. (3) Cognitive deficits - disorganized thinking, reasoning and memory. ${ }^{2}$

Current therapy for psychotic disorders is by use of either typical (e.g. haloperidol, chlorpromazine, Trifluoperazine, thioridazine etc.) or atypical antipsychotic drugs (e.g. olanzapine, clozapine, quetiapine, aripiprazole etc.). ${ }^{3}$ Besides the multitude of adverse effects seen with the typical antipsychotic drugs, many patients remain resistant in terms of cognition and other rating scales like PANSS (positive and negative scoring scale). It is assumed that $20-30 \%$ of patients who have schizophrenia do not respond to treatment with conventional antipsychotics, but even higher rates (up to 
$60 \%$ ) have been mentioned for such resistant schizophrenia. ${ }^{4}$ Such schizophrenia is commonly treated with atypical antipsychotics. The newer, atypical antipsychotic agents offer a better neurological sideeffect profile than typical antipsychotic drugs, but they are not more effective in the treatment of positive symptoms than typical agents, although there may be small differences in effects on negative symptoms and cognition. ${ }^{1}$ So there is always an ongoing need for finding newer agents for treatment of psychotic disorders.

There is strong genetic association seen in bipolar mood disorders and schizophrenia patients. ${ }^{5}$ Nimodipine is a dihydropyridine calcium channel blocker originally developed for the treatment of hypertension. It has high lipid solubility, so easily enters $\mathrm{CNS}^{6}{ }^{6}$ It has been successfully used in mood disorder treatment especially for those subclasses of bipolar disorder most resistant to therapy. But it has not yet been approved for the same, and is used off label. ${ }^{7}$ There is a possible neurotransmitter overlap seen between bipolar disorder and schizophrenia with both disorders displaying some similarities in neurotransmitter dysfunction. Many newer atypical antipsychotic agents approved for the treatment of schizophrenia are also proving useful for bipolar disorder. ${ }^{6}$ However, a potential role as an antipsychotic is still questionable. There have been studies conducted to evaluate antipsychotic activity of nimodipine, but have shown inconsistent and contradictory results. ${ }^{8,9}$

Amphetamine is used classically as a model to evaluate antipsychotic activity of drugs due to activation of postsynaptic striatal and mesolimbic dopamine receptors by released dopamine. ${ }^{10,11} \mathrm{We}$ have tried to explore methylphenidate as an alternative to induce psychosis due to its similar CNS stimulant nature and pharmacological actions. $^{12}$ It has been shown preliminarily to induce stereotypy in animals. ${ }^{13}$ Based on these findings, it was planned to demonstrate and explore use of methylphenidate as an alternative model to induce psychosis in albino mice and to re-evaluate the antipsychotic effect of nimodipine alone and in combination with haloperidol. Activity of nimodipine was also evaluated on the haloperidol induced catalepsy test for its EPS (extra pyramidal symptoms) potential.

\section{METHODS}

\section{Drugs and chemicals}

Inj Serenace (Haloperidol 5mg/ml- RPG LIFE, India), Tab Addwise (Methylphenidate - 10 mg - Sun Pharma, India), Tab Nimodip (Nimodipine $30 \mathrm{mg}$ - SUV Pharma, India). The drugs were purchased from the companies through their authorized representatives.

\section{Animals}

Adult Swiss albino mice $(25-30 \mathrm{~g})$ of either sex were procured from the Central Animal House, M.G.M. Medical College, Indore and acclimatized for a period of 7 days at room temperature $\left(25 \pm 2{ }^{\circ} \mathrm{C}\right)$ and $50 \pm 15 \%$ relative humidity. They were housed in a standard cage and maintained on standard pellets and water ab libitum. The animals were used as per standard animal care guidelines. The study was carried out in the Department of Pharmacology, M.G.M. Medical College, Indore (M.P.), India. The study protocol was approved by the Institutional Animal Ethics Committee (IAEC) registered with CPCSEA (Reg. no. 709).

\section{Methylphenidate induced psychosis}

The psychosis was induced in mice by using methylphenidate in dose of $5 \mathrm{mg} / \mathrm{kg}$ by suspending in 2 $\%$ gum acacia. ${ }^{13}$ Methylphenidate, by stimulating dopaminergic receptors in mesolimbic system, can induce a stereotypy behavior (purposeless, repeated and abnormal facial movements like gnawing, paw leaking and sniffing) in animals. ${ }^{14}$ This behavior is presently considered equivalent to psychotic features and used for evaluating the antipsychotic potential of new drugs. ${ }^{10}$ Mice of either sex were selected and they were randomly divided into 6 groups ( $n=6$ in each group):-

Group I- Control - Gum acacia 2\% (0.2 ml). Group II- Methylphenidate alone group ( $5 \mathrm{mg} / \mathrm{kg})$. Group III- Methylphenidate $(5 \mathrm{mg} / \mathrm{kg})$ and Haloperidol $(0.2 \mathrm{mg} / \mathrm{kg})$.

Group IV- Methylphenidate $(5 \mathrm{mg} / \mathrm{kg})$ and Nimodipine (2.5 $\mathrm{mg} / \mathrm{kg})$.

Group V- Methylphenidate $(5 \mathrm{mg} / \mathrm{kg})$ and Nimodipine $(5 \mathrm{mg} / \mathrm{kg})$.

Group VI - Methylphenidate $(5 \mathrm{mg} / \mathrm{kg})$ and Nimodipine $(5 \mathrm{mg} / \mathrm{kg})$ and Haloperidol $(0.1 \mathrm{mg} / \mathrm{kg})$.

All drugs were given by intra-peritoneal route (i.p). The drugs nimodipine and haloperidol were given half an hour before methylphenidate injection (pretreatment) and animals placed in stainless-steel cages and number of stereotypy movements were recorded for 10 mins after half an hour of methylphenidate injection. ${ }^{15}$ Video recording was done for all groups of animals. Stereotypic behaviour was characterized by continuous sniffing, licking or chewing and compulsive gnawing. An animal was considered to be protected, if the stereotypic behaviour is reduced or abolished.

\section{Haloperidol induced catalepsy}

Catalepsy in rats is defined as a failure to correct an externally imposed, unusual posture over a prolonged period of time. Haloperidol blocks dopamine D2 receptors and produces a state of catalepsy in animals by reducing dopaminergic transmission in basal ganglion. Enhanced stimulation of the intrinsic central cholinergic 
system has also been implicated in haloperidol-induced catalepsy. ${ }^{16}$ Cataleptic symptoms in rodents have been compared to the Parkinson-like extrapyramidal side effects seen clinically with administration of antipsychotic drugs. ${ }^{17}$

Mice of either sex were selected and they were randomly divided into 5 groups $(\mathrm{n}=6$ in each group):-

Group I- Control - Gum acacia 2\% (0.2 ml).

Group II- Haloperidol alone $(1 \mathrm{mg} / \mathrm{kg}){ }^{16}$

Group III- Haloperidol (1mg/kg) and Trihexyphenidyl $(10 \mathrm{mg} / \mathrm{kg}){ }^{16}$

Group IV- Haloperidol $(1 \mathrm{mg} / \mathrm{kg})$ and Nimodipine $(2.5$ $\mathrm{mg} / \mathrm{kg}$ ).

Group V- Haloperidol (1mg/kg) and Nimodipine (5 $\mathrm{mg} / \mathrm{kg}$ ).

All drugs were given by intra-peritoneal route (i.p). The drugs nimodipine and trihexyphenidyl were given half hour before haloperidol injection. Thirty minutes after administration of vehicle/drugs, haloperidol at the dose of $1 \mathrm{mg} / \mathrm{kg}$ body weight, in the form of an injectable solution constituted in gum acacia, was administered to induce catalepsy. The degree of catalepsy was measured at 30 , 60 and $120 \mathrm{~min}$ after haloperidol administration. Catalepsy was measured as the time the animal maintained an imposed position with both front limbs raised and resting on a four centimeter high wooden bar. The end point of catalepsy was considered to occur when both front paws were removed from the bar or if the animal moved its head in an exploratory manner. If the animal maintained the imposed posture for at least twenty seconds it was said to be cataleptic and given one point. One extra point was given for every twenty seconds further that the animal continued to maintain the cataleptic posture. A cut-off cataleptic score of 60 (corresponding to $20 \mathrm{~min}$ ) was used during the recording of observations. ${ }^{18}$

\section{Statistical analysis}

Data were expressed as Mean \pm SEM and statistical analysis was carried out by one way ANOVA followed by Bonferroni's test using SPSS software version 20.0. Value of $\mathrm{p}<0.05$ was considered to be statistically significant.

\section{RESULTS}

In the study to use methylphenidate for induction of psychosis and evaluation of antipsychotic effect of nimodipine, the methylphenidate group (II) showed the same pattern of characteristic stereotypy movements as are observed generally with amphetamine when it is used to induce psychosis in rodents - gnawing, sniffing and licking - and the number of movements $(48.8 \pm 2.478)$ were significantly higher than control group (I) which hardly showed any such movements. Similar pattern of movements were observed in all the other groups in which animals were administered methylphenidate. The number of these stereotypy abnormal movements in standard group (III) given haloperidol $0.2 \mathrm{mg} / \mathrm{kg}$ were significantly reduced $(28.2 \pm 2.53)$ as compared to the methylphenidate alone group in ten minutes. This was further evidence of induction of psychosis in the animals (Table 1).

\section{Table 1: Effect of nimodipine on methylphenidate induced psychosis.}

\begin{tabular}{|llll|}
\hline $\begin{array}{l}\mathbf{N} \\
\text { 0. }\end{array}$ & $\begin{array}{l}\text { Grouping and } \\
\text { drugs }(\mathrm{n}=6)\end{array}$ & Dose & $\begin{array}{l}\text { No. of } \\
\text { Stereotypy } \\
\text { movements } \\
\text { (Mean } \pm \text { SEM) }\end{array}$ \\
\hline 1 & $\begin{array}{l}\text { Gum acacia } \\
\text { (Control) }\end{array}$ & $\begin{array}{l}2 \mathrm{~g} / 100 \\
\mathrm{ml}, 0.2 \mathrm{ml}\end{array}$ & $0.14 \pm 0.343$ \\
\hline 2 & Methylphenidate & $5 \mathrm{mg} / \mathrm{kg}$ & $48.8 \pm 2.478^{\mathrm{a}}$ \\
\hline 3 & $\begin{array}{l}\text { Methylphenidate }+ \\
\text { haloperidol }\end{array}$ & $\begin{array}{l}5 \mathrm{mg} / \mathrm{kg}+ \\
0.2 \mathrm{mg} /\end{array}$ & $28.2 \pm 2.53^{\mathrm{a}, \mathrm{b}, \mathrm{d}}$ \\
\hline 4 & $\begin{array}{l}\text { Methylphenidate }+ \\
\text { nimodipine }\end{array}$ & $\begin{array}{l}5 \mathrm{mg} / \mathrm{kg}+ \\
2.5 \mathrm{mg} / \mathrm{kg}\end{array}$ & $49.6 \pm 2.63^{\mathrm{a}}$ \\
\hline 5 & $\begin{array}{l}\text { Methylphenidate }+ \\
\text { nimodipine }\end{array}$ & $\begin{array}{l}5 \mathrm{mg} / \mathrm{kg}+ \\
5 \mathrm{mg} / \mathrm{kg}\end{array}$ & $29.8 \pm 1.88^{\mathrm{a}, \mathrm{b}, \mathrm{d}}$ \\
\hline & $\begin{array}{l}\text { Methylphenidate }+ \\
\text { nimodipine } \\
\text { +haloperidol }\end{array}$ & $\begin{array}{l}5 \mathrm{mg} / \mathrm{kg}+ \\
5 \mathrm{mg} / \mathrm{kg}+ \\
0.1 \mathrm{mg} / \mathrm{kg}\end{array}$ & $3.125^{\mathrm{a}, \mathrm{b}, \mathrm{c}, \mathrm{d}, \mathrm{e}}$ \\
\hline
\end{tabular}

One way ANOVA followed by Bon Ferroni's test; values expressed in mean \pm SEM

df $=5,30 ;{ }^{a} \mathrm{p}<0.05$ as compared to control; ${ }^{\mathrm{b}} \mathrm{p}<0.05$ as compared to methylphenidate; ${ }^{c} p<0.05$ as compared to haloperidol; ${ }^{\mathrm{d}} \mathrm{p}<0.05$ as compared to nimodipine $2.5 \mathrm{mg} / \mathrm{kg}$; ${ }^{\mathrm{e}} \mathrm{p}<0.05$ as compared to nimodipine $5 \mathrm{mg} / \mathrm{kg}$

Table 2: Effect of nimodipine on haloperidol induced catalepsy in albino mice.

\begin{tabular}{|c|c|c|c|c|}
\hline \multirow[t]{2}{*}{ Group $(n=6)$} & \multirow[t]{2}{*}{ Dose } & \multicolumn{3}{|c|}{ Mean catatonia scores } \\
\hline & & $30 \mathrm{~min}$ & $60 \mathrm{~min}$ & $\begin{array}{l}120 \\
\text { min }\end{array}$ \\
\hline $\begin{array}{l}\text { Group I - } \\
\text { Control : Gum } \\
\text { acacia }\end{array}$ & $\begin{array}{l}2 \% \\
(0.2 \\
\mathrm{ml})\end{array}$ & $\begin{array}{l}0.13 \pm \\
0.354\end{array}$ & $\begin{array}{l}0.13 \pm \\
0.354\end{array}$ & $\begin{array}{l}0.25 \pm \\
0.463\end{array}$ \\
\hline $\begin{array}{l}\text { Group II - } \\
\text { Haloperidol }\end{array}$ & $\begin{array}{l}1 \\
\mathrm{mg} / \mathrm{kg}\end{array}$ & $\begin{array}{l}15.25 \pm \\
2.053\end{array}$ & $\begin{array}{l}26.75 \pm \\
2.550\end{array}$ & $\begin{array}{l}32.50 \pm \\
5.928\end{array}$ \\
\hline $\begin{array}{l}\text { Group - III } \\
\text { Haloperidol + } \\
\text { Trihexyphenidyl }\end{array}$ & $\begin{array}{l}1+10 \\
\mathrm{mg} / \mathrm{kg}\end{array}$ & $\begin{array}{l}10.25 \pm \\
1.669^{*}\end{array}$ & $\begin{array}{l}14.88 \pm \\
1.885^{*}\end{array}$ & $\begin{array}{l}19.75 \pm \\
2.121^{*}\end{array}$ \\
\hline $\begin{array}{l}\text { Group III - } \\
\text { Haloperidol + } \\
\text { Nimodipine }\end{array}$ & $\begin{array}{l}1+2.5 \\
\mathrm{mg} / \mathrm{kg}\end{array}$ & $\begin{array}{l}15.62 \pm \\
2.066\end{array}$ & $\begin{array}{l}26.88 \pm \\
3.399\end{array}$ & $\begin{array}{l}32.63 \pm \\
4.406\end{array}$ \\
\hline $\begin{array}{l}\text { Group IV - } \\
\text { Haloperidol + } \\
\text { Nimodipine }\end{array}$ & $\begin{array}{l}1+5 \\
\mathrm{mg} / \mathrm{kg}\end{array}$ & $\begin{array}{l}17.50 \pm \\
3.586\end{array}$ & $\begin{array}{l}28.75 \pm \\
5.726\end{array}$ & $\begin{array}{l}31.25 \pm \\
8.615\end{array}$ \\
\hline
\end{tabular}

One way ANOVA followed by Bon Ferroni's test; Values expressed in mean \pm SEM

$\mathrm{df}=4,25 ;{ }^{*} \mathrm{p}<0.05$ compared to all groups 
There was no significant reduction in number of abnormal movements with nimodipine $2.5 \mathrm{mg} / \mathrm{kg}$ (groupIV) but statistically significant reduction $(29.8 \pm 1.88)$ was seen with nimodipine in a dose of $5 \mathrm{mg} / \mathrm{kg}$ (group-V) as compared to methylphenidate alone group ( $p<0.05)$. Although this reduction of abnormal movements was slightly lesser than haloperidol but the difference was not statistically significant ( $p>0.05)$. A very important finding was that nimodipine $5 \mathrm{mg} / \mathrm{kg}$ when given in combination with half of the therapeutic dose of haloperidol $0.1 \mathrm{mg} / \mathrm{kg}$ (group VI) showed significantly better results, $\mathrm{p}<0.05$, than all other groups including the full therapeutic dose of haloperidol $0.2 \mathrm{mg} / \mathrm{kg}$ (group II).

In the haloperidol induced catalepsy test to evaluate EPS potential, nimodipine in both doses of 2.5 and $5 \mathrm{mg} / \mathrm{kg}$ did not show any significant increase or decrease in the catalepsy scores as compared to the haloperidol alone group at all the time intervals (up to 120 mins) (Table 2).

\section{DISCUSSION}

\section{Methylphenidate as a model for psychosis (stereotypy)}

From the results shown above, we could clearly demonstrate that methylphenidate induces the same kind of stereotypy behavior (or movements) as amphetamine, which are considered equivalent to psychotic behavior in animals. The type of behavioral stereotypy- gnawing, sniffing, licking, and the significant reduction of the same brought by a typical antipsychotic haloperidol, strongly suggests that methylphenidate induces psychosis similar to the standard amphetamine model. Methylphenidate is a piperidine derivative structurally related to amphetamine and large doses produce signs of generalized CNS stimulation. ${ }^{12}$ Methylphenidate is used for ADHD patients and also abused nowadays; it has been shown to induce clinical psychosis apart from other neuropsychiatric symptoms as adverse effects. ${ }^{14}$ It has also been shown previously that when used between doses of $10-30 \mathrm{mg} / \mathrm{kg}$ body weight in rodents, mmethylphenidate promotes a dose dependent behavioural profile that is very comparable to that of amphetamine. ${ }^{13}$ In this study by Kuczenski and Segal, methylphenidate promoted a dose-dependent pattern of locomotion and stereotypy similar to results with amphetamine in previous studies. ${ }^{19,20}$ Methylphenidate is classified as a CNS stimulant. Its proposed mechanism of action is the release and increase of CNS dopamine.This release is secondary to its effect on the dopamine transport mechanism, which results in an increased amount of postsynaptic dopamine. ${ }^{14}$

We found in a pilot study that methylphenidate showed significant stereotypy at dose of $5 \mathrm{mg} / \mathrm{kg}$ itself. So we decided to use this dose of methylphenidate and could find significant characteristic stereotypy behavior (sniffing, gnawing, paw licking) and also a hyper locomotion response. It is suggested that methylphenidate, like amphetamine, promotes a dose- dependent increase in extracellular dopamine in the caudate putamen and extracellular norepinephrine in the hippocampus, but has no effect on 5-HT. Methylphenidate binds to the dopamine transporter and inhibits dopamine uptake with a potency similar to that of cocaine. It has also been shown to bind to the norepinephrine transporter and to be an effective in vitro inhibitor of NE uptake but it appears to have very weak potency both in binding to the 5-HT transporter and as an inhibitor of 5-HT uptake. ${ }^{13}$

It has been shown that disruption of 5-HT function appears to enhance the locomotor effects of amphetamine while attenuating the appearance of focused stereotypies. ${ }^{21}$ So this may contribute to a more marked stereotypy response seen with methylphenidate and not a prominent hyper locomotion, as observed. It has also been shown that stereotypy was not seen with methylphenidate in dopamine depleted animals or knocked in mice. ${ }^{22}$ Hence, on the above grounds, we recommend that methylphenidate can be used and further established as an alternative model for inducing psychosis in animals for evaluation of newer typical antipsychotics which work mainly through dopamine pathways.

\section{Antipsychotic potential of nimodipine and possible mechanisms}

Our results showed that nimodipine at a dose of $5 \mathrm{mg} / \mathrm{kg}$ showed antipsychotic effects comparable with the standard drug haloperidol. More importantly, nimodipine at this dose of $5 \mathrm{mg} / \mathrm{kg}$ used in combination with half of the therapeutic dose of haloperidol $(0.1 \mathrm{mg} / \mathrm{kg})$, showed effects significantly better than those of full therapeutic dose of haloperidol $(0.2 \mathrm{mg} / \mathrm{kg})$. Nimodipine, due its lipid solubility (CNS entry) and relative lack of significant adverse effects has a strong potential to be used as an antipsychotic, especially as an adjunct to the typical antipsychotics. The unfavorable pharmacokinetics of nimodipine; short half-life of and short duration of action, probably limits its potential to being an adjunctive drug to conventional (typical) antipsychotics whereby it can possibly reduce the dose requirements and the numerous troublesome adverse effects. ${ }^{23}$

\section{Antidopaminergic activity of nimodipine}

The well-known dopamine hypothesis suggests that over activity of dopaminergic neurotransmission is believed to be responsible for functional psychosis especially schizophrenia, All commercially available antipsychotic drugs reduce dopaminergic neurotransmission. This finding implicates $\mathrm{D}_{2}$ blockade (or, in the case of aripiprazole, modulation of DA activity) as the primary therapeutic mechanism. There may also be an excess activity of serotonin or hyper excitability of 5HT2A/C receptors as evident by use of atypical antipsychotics like clozapine and others mainly for negative symptoms. ${ }^{24}$ 
So most contemporary pathophysiological models assume that psychotic symptoms are triggered by a dysregulation of dopaminergic activity in the brain, a theory that is tightly linked to the serendipitous discovery of the first effective antipsychotic agents in the early 1950s. There is common evidence available for role of multiple calcium channels being responsible for release of multiple neurotransmitters in CNS including dopamine and corresponding neural activity. ${ }^{25}$ It has been elucidated that dopamine depends on $\mathrm{Ca}++$ for amphetamine induced release. ${ }^{26}$ It has also been reported that nimodipine, by its calcium channel blocking activity, inhibits release of dopamine along with decreasing dopamine synthesis in the mouse brain. ${ }^{27}$ So this could explain the antidopaminergic activity of nimodipine in reference to the psychosis induced by methylphenidate.

Our findings are consistent with those of Khanzode SD et al who performed the study in a slightly higher dose range, but do not match with the results of Kaygisiz et al which showed a negative response of nimodipine in combination with ziprasidone, an atypical antipsychotic and no antipsychotic effect of nimodipine alone. But the dose used in the latter study was $0.5 \mathrm{mg} / \mathrm{kg}$, which may be the reason behind the non-congruence with our findings. ${ }^{8,9}$ Studies done at even higher doses of $10-20$ $\mathrm{mg} / \mathrm{kg}$, by different routes have also shown reduction of stimulant induced hyperlocomotion. ${ }^{28,29}$ Importantly, the significantly better antipsychotic activity shown by combination of nimodipine $(5 \mathrm{mg} / \mathrm{kg})$ and half standard dose of haloperidol $(0.1 \mathrm{mg} / \mathrm{kg})$, further reiterates these findings and gives evidence of the possible additive antidopaminergic activity of nimodipine in combination with haloperidol.

\section{Role of calcium in psychosis via the cholinergic system}

It has been postulated by Yarlagadda and Clayton that acetylcholine dysregulation precedes dopamine dysregulation in schizophrenia. ${ }^{30}$ There is a pathophysiologic role of cholinergic systems via calcium release in schizophrenia and acetylcholine's involvement precedes dopamine regulation in processing information. The cholinergic system has a major impact on cognitive abilities, especially learning and memory, through acetylcholine. It has been further stated that calcium starts acting right from the reception of a signal to the processing of information into assemblies by dopamine in higher functioning areas, such as the prefrontal cortex. This central role highlights the unifying effects of calcium in the regulatory mechanisms of schizophrenia.

Cerebroselective blockers of the L-type calcium channels, like nimodipine, are currently mainly used during cerebrovascular accidents (CVA). ${ }^{31}$ With no reported side effects and safety in pregnancy, it has been advocated that this CNS calcium channel blocker should be further studied for antipsychotic use especially in the elderly.

\section{Usefulness of nimodipine in bipolar diseases and its similarity with psychosis}

It has been concretely suggested that all the neural mechanisms that are hypothesized to explain various psychopharmacological treatments of bipolar illness involve functions that are critically controlled by calcium. Moreover, lithium's prophylactic action can also be almost completely accounted for by the calciumdependent processes. Similarities exist between the actions of lithium and calcium antagonists like verapamil and nimodipine. Calcium antagonists have been found useful in this indication by a number of investigators. ${ }^{32}$

There is a gathering notion that both bipolar disorder and schizophrenia can, in fact, be considered as part of an expanded psychiatric continuum. Both bipolar disorder and schizophrenia demonstrate a high degree of genetic transmissibility. Family and twin studies have suggested hereditary overlap between the two disorders. Certain susceptibility markers appear to be located on the same chromosomes for both diseases. There is also demonstration of similarities in neurotransmitter dysfunction. As further indirect evidence of a possible association, many newer atypical antipsychotic agents approved for the treatment of schizophrenia are also proving useful for bipolar disorder. ${ }^{5}$

Thus if nimodipine has use (off label) in bipolar disorders, it should have potential for treatment of psychosis too.

\section{Nimodipine's effect on EPS potential}

The haloperidol induced catalepsy test showed that nimodipine, at both doses used in the study, neither increases nor decreases the catatonia scores significantly although there is a marginal potentiation of catalepsy with the dose of $5 \mathrm{mg} / \mathrm{kg}$ at 30 and 60 mins. ( $>>0.05$ ) This indicates that nimodipine does not have a significant potential to induce or ameliorate extra pyramidal symptoms, which are a characteristic of the typical antipsychotic drugs.

This finding is not in agreement with the study by Khanzode SD et al where a significant EPS potential was displayed by nimodipine. It may be hypothesized that although nimodipine inhibits dopamine activity (thus the antipsychosis), it may not modify the dopamine/acetylcholine balance significantly at the levels of basal ganglion at the doses used in this study. Furthermore nimodipine has been suggested as useful adjunctive treatment of tardive dyskinesia's which is actually a delayed type of extra pyramidal symptom due to typical antipsychotics. ${ }^{33}$

The insignificant effect on haloperidol induced catalepsy would be an advantageous property, as there does not seem to be a potential to induce extrapyramidal symptoms, unlike the typical antipsychotics, making the 
combination more feasible and favorable if both drugs are combined in lower doses.

\section{CONCLUSION}

To conclude, we would like to state that the study successfully demonstrates the potential of using and establishing methylphenidate as an alternative model for induction of psychosis in animals. The study provides a preliminary confirmation of the antipsychotic potential of the calcium channel blocker Nimodipine, also providing strength to the correlation that is being explored between the neurotransmitter abnormalities and pathogenesis of bipolar disorders and a psychotic disorder like schizophrenia. It should be further explored for use in psychosis, especially as a good adjunct to the conventional treatment with typical antipsychotics.

\section{ACKNOWLEDGEMENTS}

The authors would like to acknowledge the faculty and staff of M.G.M. Medical College, Indore and N.S.C.B. Medical College, Jabalpur for their support and cooperation during the conduct of this study.

Funding: No funding sources

Conflict of interest: None declared

Ethical approval: The study was approved by the Institutional Animal Ethics Committee

\section{REFERENCES}

1. Baldessarani RJ, Tarzai FI. Drug therapy of psychosis and mania. In: Brunton L, Lazo JS, Parker KL, eds. Goodman \& Gilman's The Pharmacological Basis of Therapeutics. 11th ed. New York, NY: McGraw-Hill. 2006:461-80.

2. Schizophrenia. In: Sadock BJ, Sadock VA, eds. Synopsis of psychiatry: Behavioral Sciences/clinical Psychiatry.10th ed. Philadelphia, PA: Lippincott Williams \& Wilkins. 2007:410-520.

3. DeBattista C. Antipsychotic agents and lithium. In: Katzung BG, Trevor AJ, eds. Basic \& clinical pharmacology. $13^{\text {th }}$ ed. New Delhi, India: Mc Graw Hill Education (India) private limited. 2015:490-509.

4. Solanki RK, Singh P, Munshi D. Current perspectives in the treatment of resistant schizophrenia. Indian J Psychiatry. 2009;51(4):25460.

5. Möller HJ. Bipolar disorder and schizophrenia: distinct illnesses or a continuum? J Clin Psychiatry. 2003;64(6):23-7.

6. Bekker A, Haile M, Li YS, Galoyan S, Garcia E, Quartermain D, et al. Nimodipine prevents memory impairment caused by nitroglycerin-induced hypotension in adult mice. Anesth Analg. 2009;109(6):1943-8.

7. Goodnick PJ. The use of nimodipine in the treatment of mood disorders. Bipolar Disord. 2000;2(3):16573.
8. Kaygisiz B, Ozdemir M, Baydemir C. Modulation of the antipsychotic Effect of Ziprasidone with Nimodipine. Bulletin of Clinical Psychopharmacology. 2011;21(3):186-92.

9. Khanzode SD, Belorkar NR, Gosavi DD. Effect of pretreatment of nimodipine and nitrendipine on some dopaminergically mediated behaviours in rats. Indian J Pharmacol. 2000;32(3):235-8.

10. Inhibition of amphetamine stereotypy in rats. Chapter E.5.3.2. In: Vogel HG, ed. Drug Discovery and Evaluation. Pharmacological assays. $2^{\text {nd }}$ ed. Heidelberg, Germany: Springer. 2002:535-37.

11. Randrup A, Munkavad I. Pharmacology and physiology of stereotyped behaviour. Psych J Research. 1974;11:1-10.

12. Westfall TC, Westfall DP. Adrenergic agonists and antagonists. In: Brunton L, Chabner B, Knollman B, eds. Goodman \& Gilman's The Pharmacological Basis of Therapeutics. 12th ed. New York, NY: McGraw-Hill. 2011:299.

13. Kuczenski R, Segal DS. Effects of Methyiphenidate on Extracellular Dopamine, Serotonin, and Norepinephrine: Comparison with Amphetamine. J. Neurochem. 1997;68(5):2032-7.

14. Morton WA, Stockton GG. Methylphenidate Abuse and Psychiatric Side Effects. Prim Care Companion J Clin Psychiatry 2000;2(5):159-64.

15. Balcioglu A, Ren JQ, McCarthy D, Spencer TJ, Biederman J, Bhide PG. Plasma and brain concentrations of oral therapeutic doses of methylphenidate and their impact on brain monoamine content in mice. Neuropharmacology. 2009;57(7-8):687-93.

16. Nishchal BS, Rai S, Prabhu MN, Ullal SD, Rajeswari S, Gopalakrishna HN. Effect of Tribulus terrestris on haloperidol-induced catalepsy in mice. Indian J Pharm Sci. 2014;76(6):564-67.

17. Catalepsy in rodents. Chapter E. 5.2.4. Vogel HG, ed. In: Drug discovery and evaluation. Pharmacological Assays. $2^{\text {nd }}$ ed. Heidelberg, Germany: Springer. 2002:531.

18. Nair V, Arjuman A, Dorababu P, Gopalakrishna HN, Rao UC, Mohan L. Effect of NR-ANX-C (a polyherbal formulation) on haloperidol induced catalepsy in albino mice. Indian $\mathbf{J}$ Med Res. 2007;126(5):480-84.

19. Browne RG, Segal DS. Metabolic and experiential factors in the behavioural response to repeated amphetamine. Pharmacol Biochem Behav. 1977;6(5):545-52.

20. Segal DS, Kuczenski R. Behavioral pharmacology of amphetamine, in Amphetamine and Its Analogs. Cho AK, Segal DS, eds. In: Psychopharmacology, Toxicology and Abuse. 1st ed. San Diego, CA: Academic Press. 1994:115-50.

21. Neill DB, Grant LD, Grossman SP. Selective potentiation oflocomotor effects of amphetamine by midbrain raphe lesions. Physiol Behav. 1972;9(4):655-57. 
22. Tilley MR, Gu HH. The effects of methylphenidate on knockin mice with a methylphenidate-resistant dopamine transporter. J Pharmacol Exp Ther. 2008;327(2):554-60.

23. Chakrabarti A, Saini HK, Garg SK. Dose-finding study with nimodipine: a selective central nervous system calcium channel blocker on aminophylline induced seizure models in rats. Brain Res Bull. 1998;45(5):495-9.

24. Meyer JM. Pharmacotherapy of psychosis and mania. In: Brunton L, Chabner B, Knollman B, eds. Goodman \& Gilman's The Pharmacological Basis of Therapeutics. 12th ed. New York, NY: McGrawHill. 2011:417-9.

25. Molinoff PB. Neurotransmission and the central nervpus system. In: Brunton L, Chabner B, Knollman B, eds. Goodman \& Gilman's The Pharmacological Basis of Therapeutics. 12th ed. New York, NY: McGraw-Hill. 2011:367-70.

26. Crespi D, Mennini T, Gobbi M. Carrier dependent and $\mathrm{Ca}++$ dependent 5-HT and DA release induced by amphetamine, 3,4 methelendioxmethyl amphetamine, p-chloramphetamine and fenfluramine. Br J Pharmacol. 1997;121(8):1735-43.

27. Pileblad E, Carlsson A. The Ca2+-antagonist nimodipine decreases and Ca2+-agonist Bay-K-8644 increases catacholamine synthesis in mouse brain. Neuropharmacol. 1987;26(1):101-5.
28. Czyrak A, Mogilnicka E, Siwanowicz J, Maj J. Some behavioural effects of repeated administration of calcium channel antagonists. Pharmacol Biochem Behav. 1990;35(3):557-60.

29. Biala G, Weglinska B. Calcium channel antagonists attenuate crosssensitization to the rewarding and/or locomotor effects of nicotine, morphine and MK801. J Pharm Pharmacol. 2004;56(8):1021-8.

30. Yarlagadda A, Clayton AH. Role of Cholinergic System and Calcium Synchronization in Schizophrenia. Psychiatry (Edgmont). 2009;6(4):3741.

31. Worthley LI, Holt AW. Acute haemorrhagic stroke. Crit Care Resusc. 2002;2(3):209-19.

32. Sarfati Y, Spadone C, Vanelle JM, Lôo H. Calcium antagonists and lithium in preventive treatment of manic-depressive Encephale.1996;22(2):149-53. disorder.

33. Essali A, Deirawan H, Soares-Weiser K, Adams CE. Calcium channel blockers for neuroleptic-induced tardive dyskinesia. Cochrane Database Syst Rev. 2011;9(11):CD000206.

Cite this article as: Tanwani $\mathrm{H}$, Pandey SP, Atal S, Nyati P. Evaluation of anti-psychotic effect of nimodipine using methylphenidate as a model to induce psychosis in albino mice. Int $\mathrm{J}$ Basic Clin Pharmacol 2015;4:1047-53. 